\title{
PERSEPSI SISWA TENTANG KOMUNIKASI INTERPERSONAL GURU DI SEKOLAH MENENGAH KEJURUAN NEGERI 5 PADANG
}

Riri Suliyarti ${ }^{1}$, Nurhizrah Gistituati ${ }^{2}$, Rusdinal ${ }^{3}$, Irsyad ${ }^{4}$

${ }^{1}$ Administrasi Pendidikan, Universitas Negeri Padang $1,{ }^{2}$ Administrasi Pendidikan, Universitas Negeri Padang 2,

${ }^{3}$ Administrasi Pendidikan, Universitas Negeri Padang 3, ${ }^{4}$ Administrasi Pendidikan, Universitas Negeri Padang 4

Riri Suliyarti ${ }^{1}$, e-mail: ririsuliyarti@gmail.com

Nurhizrah Gistituati ${ }^{2}$, e-mail: gistituatinurhizrah@gmail.com

Rusdinal $^{3}$, e-mail: rusdinal@ fip.unp.ac.id

Irsyad $^{4}$, e-mail: : irsyad1122@gmail.com

\begin{abstract}
This study aims to determine: 1) students 'perceptions about openness of interpersonal communication of teachers, 2) students' perceptions of empathy in teacher's interpersonal communication, 3) students 'perceptions of supportive attitudes in teacher's interpersonal communication, 4) students' perceptions of positive attitudes of interpersonal communication of teachers, 5) students' perceptions about the similarity of teacher's interpersonal communication. This research is quantitative descriptive, and data collection techniques are using a questionnaire. The results showed that students' perceptions of teacher interpersonal communication were; 1) openness with $79.37 \%$ achievement which is in good enough criteria, 2) empathy with $86.80 \%$ achievement are in good criteria, 3) mutual support with $83.41 \%$ achievement in good criteria, 4) positive attitude with achievement of $79.67 \%$ in the category is quite good, 5) similarity with achievement of 76.67 in the criteria is quite good, so it can be concluded that the interpersonal communication of teachers in SMK 5 Padang according to students' perceptions with a score of $81.18 \%$ on good criteria.
\end{abstract}

\begin{abstract}
Abstrak
Penelitian ini bertujuan untuk mengetahui : 1) persepsi siswa tentang keterbukaan komunikasi interpersonal guru, 2) persepsi siswa tentang empati dalam komunikasi interpersonal guru, 3) persepsi siswa tentang sikap mendukung dalam komunikasi interpersonal guru, 4) persepsi siswa tentang sikap positif komunikasi interpersonal guru, 5) persepsi siswa tentang kesamaan komunikasi interpersonal guru. Penelitian ini bersifat deskriptif kuantitatif, serta teknik pengumpulan data menggunakan angket. Hasil penelitian menunjukkan bahwa persepsi siswa tentang komunikasi interpersonal guru adalah; 1) keterbukaan dengan capaian 79,37\% yang berada pada kriteria cukup baik, 2) empati dengan capaian $86,80 \%$ berada pada kriteria baik, 3) sikap saling mendukung dengan capaian $83,41 \%$ dalam kriteria baik, 4) sikap positif dengan capaian 79,67\% dalam kategori cukup baik, 5) kesamaan dengan capaian 76,67 dalam kriteria cukup baik, jadi dapat disimpulkan bahwa komunikasi interpersonal guru di SMKN 5 Padang menurut persepsi siswa dengan skor $81,18 \%$ pada kriteria baik.
\end{abstract}

Kata Kunci: persepsi siswa; komunikasi interpersonal guru

How to Cite: Suliyarti, Riri, Nurhizrah Gistituati, Rusdinal dan Irsyad. 2020. "Persepsi Siswa Tentang Komunikasi Interpersonal Guru di SMK Negeri 5 Padang". Educational Administration and Leadership, Vol 1 (2): pp. 1-7, DOI: doi.org/10.24036/jeal.v1i2

\section{Pendahuluan}

Proses penyampaian pesan dari komunikator kepada komunikan yang berupa pesan verbal ataupun nonverbal melalui sebuah alat agar pesan yang disampaikan dapat dipahami dan tujuan dari pesan tersebut 
dapat tercapai sehingga dapat mengubah tingkah laku disebut dengan komunikasi interpersonal (Muhammad, 2009; Gistituati, 2009; Liliweri, 2015). Komunikasi interpersonal sangat penting dalam suatu organisasi karena dengan adanya komunikasi yang baik suatu organisasi dapat berjalan dengan lancar dan sukses mencapai tujuannya, dengan adanya komunikasi interpersonal yang baik di dalam organisasi dapat mengurangi konflik (Üstüner and Kiş 2014). Komunikasi interpersonal sangat penting untuk meningkatkan hubungan antar individu, menghindari dan mengatasi konflik pribadi, mengurangi ketidakpastian, berbagi pengetahuan dan pengalaman dengan orang lain, mengendalikan perilaku, memberi motivasi, sebagai pernyataan emosi dan memberikan suatu informasi (Cangara 2004). Beberapa hasil penelitian juga menunjukan bahwa komunikasi interpersonal berpengaruh terhadap kinerja pegawai (Remanda, 2012; Wadudu, 2013; Gustyawan, 2015), berpengaruh terhadap kepuasan kerja pegawai (Rizaldi and Nuraeni 2013); Fauziah, 2014), serta berhubungan dengan iklim organisasi (Azrimul \& Masyhuri, 2013; Wijaya, 2013).

Komunikasi interpersonal juga sangat penting bagi guru di sekolah. Seorang guru dalam proses belajar mengajar di sekolah harus mampu berkomunikasi dengan baik, baik dengan kepala sekolah, sesama guru, tenaga administrasi maupun siswa. Bagi seorang guru yang tidak mampu berkomunikasi secara efektif akan sangat berpengaruh, tidak hanya terhadap persepsi siswa tapi juga terhadap hasil belajar siswanya (Gistituati, 2009, Henderson, 2013; Al-Madani, 2014). Oleh sebab itu guru dituntut untuk melakukan tugasnya seprofesional mungkin salah satunya dengan menggunakan komunikasi yang efektif saat berkomunikasi dengan orang lain di sekolah. Melalui komunikasi khususnya komunikasi interpersonal, guru dapat mencapai tujuan pembelajaran yang telah ditentukan dengan efektif, dimana dengan adanya komunikasi interpersonal memudahkan komunikasi antar guru dan siswa. Beberapa hasil penelitian juga menunjukan bahwa komunikasi interpersonal guru berpengaruh terhadap motivasi belajar siswa (F. and Mawizha 2018); berpengaruh terhadap prestasi belajar siswa (Yusuf, 2017); komunikasi interpersonal guru berpengaruh terhadap perilaku belajar siswa (Fathurrohman 2018); komunikasi interpersonal guru berpengaruh terhadap minat belajar siswa (Usman 2015); berpengaruh terhadap komitmen belajar siswa (Regina 2016); serta berhubungan dengan keaktifan belajar siswa (Rozaq 2012).

Persepsi siswa tentang komunikasi interpersonal guru sebagai bahan penilaian atas komunikasi yang telah dilakukan. Melalui persepsi siswa dapat diketahui kekurangan dan kelebihan komunikasi interpersonal yang telah dilakukan oleh guru. Persepsi siswa tentang komunikasi interpersonal guru dapat mempengaruhi tingkah laku siswa dalam proses pembelajaran. Persepsi siswa tentang komunikasi interpersonal guru yang negatif akan menjadi kendala dalam proses pembelajaran nantinya. Sebaliknya jika siswa memberikan persepsi yang positif terhadap komunikasi interpersonal guru, maka siswa dapat merasa tergerak untuk meningkatkan kemampuan dalam proses pembelajaran.

Berdasarkan hasil pengamatan dan informasi pada saat melaksanakan praktek lapangan kependidikan tanggal 15 Juli s.d 25 November 2019. Pelaksanaan komunikasi interpersonal guru di SMK Negeri 5 Padang masih belum terwujud sesuai dengan yang diharapkan, hal tersebut ditandai dengan fenomena-fenomena yang terjadi sebagai berikut ini :

a. Guru mengalami kesulitan untuk dalam berbicara secara terbuka dengan siswa. Dan guru lebih memilih menyampaikan kritikannya dengan cara menyindir ataupun desas-desus dari mulut ke mulut tanpa mau menyampaikan langsung kepada siswa yang bersangkutan.

b. Guru terkesan acuh terhadap siswa yang kurang paham akan tugas atau perintah dari guru dalam sebuah pembelajaran, ataupun sekedar tahu saja tanpa ada niatan untuk membantu menjelaskan atau membantu mencarikan solusi.

c. Adanya guru yang menggunakan bahasa yang kurang baik terhadap siswa. Hal ini dilihat dari adanya guru yang memanggil siswa dengan panggilan lain bukan nama aslinya dan seolah merendahkan atau mengolok-olok siswa tersebut dengan panggilan tersebut.

d. Guru kesulitan dalam memberikan sikap pujian kepada siswa, dimana pada saat salah satu siswa mendapat sebuah prestasi di sekolah namun guru bersikap acuh tak acuh tanpa memberikan ucapan selamat kepada siswa tersebut, di sini terlihat jelas bahwa adanya kurang dukungan guru kepada siswa dalam hal pemberian penghargaan diri.

e. Adanya sikap negatif guru dalam menanggapi keluhan siswa. Guru cenderung kasar dalam menanggapi kesalahan siswa, misalnya ada siswa yang tinggal kelas, guru dengan mudahnya menyuruh mereka pindah sekolah. Dan juga guru bersikap tinggi hati saat diberi kritik yang sifatnya membangun oleh siswa. Guru tersebut beranggapan siswanya itu tidak sopan sehingga kritikkan rekannya tidak diterima atau diacuhkan begitu saja.

f. Guru sulit menumbuhkan sikap saling menghargai dan mengganggap siswa itu sama. Hal ini terlihat dari adanya guru yang meremehkan kemampuan seorang siswa dan lebih membanggakan siswa lainnya dalam bidang tersebut.

g. Guru belum menampakkan tingkat kedisiplinan yang dalam mengajar, dimana dapat dilihat banyak guru yang datang terlambat dan juga ada guru yang meninggalkan peserta didik di kelas untuk makan dan 
berbicara di kantin atau koperasi sekolah. Serta adanya kebiasaan guru datang hanya pada saat ambil daftar hadir elektronik dan saat jam mengajar dan setelah keluar kelas langsung hilang dari sekolah.

h. Adanya hubungan kurang baik antara guru dengan siswa, hal ini dilihat saat ada tanggapan kurang menyenangkan guru terhadap siswa yang pernah terlibat masalah atau percekcokan dengan guru tersebut.

i. Guru tidak menampakkan perhatian yang baik terhadap siswa. Hal ini dilihat saat adanya siswa yang keluar masuk di saat proses pembelajaran berlangsung ataupun adanya siswa yang sibuk sendiri selama mengikuti pembelajaran, guru megacuhkan saja dengan menegur seadanya, guru membiarkan saja hal semacam itu dan lanjut saja menyampaikan pembelajaran.

Tujuan penelitian ini dilakukan adalah untuk mendapatkan informasi tentang: 1) Seberapa terbukanya komunikasi interpersonal guru di SMK Negeri 5 Padang menurut persepsi siswa? 2) Seberapa tinggi menurut persepsi siswa tentang rasa empati yang diperlihatkan guru dalam komunikasi interpersonal guru di SMK Negeri 5 Padang? 3) Seberapa tinggi menurut persepsi siswa tentang sikap mendukung yang diperlihatkan guru dalam komunikasi interpersonal guru di SMK Negeri 5 Padang? 4) Seberapa baik sikap positif yang diperlihatkan guru dalam komunikasi interpersonal guru di SMK Negeri 5 Padang menurut persepsi siswa? 5) Seberapa setara komunikasi interpersonal guru di SMK Negeri 5 Padang menurut persepsi siswa?

\section{Metode Penelitian}

Jenis penelitian adalah deskriptif kuantitatif, yang mencoba memberikan gambaran suatu keadaan masa sekarang secara mendalam (Yusuf, 2017). Indikator pada penelitian ini yaitu, 1) keterbukaan, 2) sikap positif, 3) empati, 4) saling mendukung, 5) kesamaan. Populasi adalah wilayah generalisasi yang terdiri atas: obyek atau subyek yang mempunyai kualitas dan karakteristik tertentu yang ditetapkan oleh peneliti untuk dipelajari dan kemudian ditarik kesimpulannya (Sugiyono 2015), populasinya adalah seluruh siswa kelas X SMKN 5 Padang yaitu 552 orang, pengambilan sampel dilakukan dengan teknik Proportional Random Sampling yaitu 91 orang. Instrument penelitian yang digunakan dalam penelitian ini adalah angket dalam bentuk Skala Likert dengan lima laternatif jawaban yang telah melalui validitas dan reliabilitas menggunakan SPSS. Data penelitian diolah dengan menghitung frekuensi serta menentukan TCR masing-masing dari masing-masing skor jawaban menggunakan rumus rata-rata laluu dikualitatifkan menggunakan kriteria yang dikembangkan (Sudjana. 2010).

\section{Hasil dan Pembahasan}

\subsection{Hasil}

Hasil penelitian mengenai persepsi siswa tentang keterbukaan komunikasi interpersonal guru SMK Negeri 5 Padang skor tertinggi ada pada pernyataan item guru mengemukakan pendapat kepada siswa secara terbuka dengan perolehan tingkat capaian $87,25 \%$ dalam kriteria baik. Skor terendah pada pernyatan guru bersedia menerima setiap kritikan yang diberikan siswa tentang proses pembelajaran di kelas dengan perolehan tingkat capaian $72,31 \%$ dalam kategori cukup baik. Secara keseluruhan persepsi siswa tentang keterbukaan komunikasi interpersonal guru SMK Negeri 5 Padang dengan capaian 79,37\% yang berada pada kriteria cukup baik.

Hasil penelitian mengenai persepsi siswa tentang empati dalam komunikasi interpersonal guru SMK Negeri 5 Padang menunjukkan skor tetinggi berada pada pernyataan guru ikut merasa bangga jika ada siswa yang mendapatkan prestasi yang bagus, baik di dalam maupun di luar sekolah dengan perolehan 90,99\% dalam kriteria sangat baik. Kemudian skor rendah adalah guru dapat memahami perasaan siswa ketika mengalami kesulitan dalam mengerjakan tugas sekolah, yaitu 83,52\% dalam kriteria baik. Secara keseluruhan persepsi siswa tentang empati dalam komunikasi interpersonal guru SMK Negeri 5 Padang dengan perolehan tingkat capaian $86,80 \%$ berada pada kriteria baik.

Hasil penelitian persepsi siswa tentang sikap saling mendukung dalam komunikasi interpersonal guru SMK Negeri 5 Padang menunjukkan skor tertinggi ada pada pernyataan guru mengutarakan rasa bangga kepada siswa yang berhasil meraih prestasi dengan perolehan tingkat pencapaian 89,23\% dalam kriteria baik. Kemudian skor terendah terdapat pada pernyataan guru bersedia mendengarkan dengan baiik setiap keluh kesah yang disampaikan siswa dengan perolehan tingkat capaian 72,75\% dalam kriteria cukup baik. Secara keseluruhan persepsi siswa tentang sikap saling mendukung dalam komunikasi interpersonal guru SMK Negeri 5 Padang dengan perolehan timgkat capaian 83,41\% dalam kriteria baik.

Hasil penelitian persepsi siswa tentang sikap positif dalam komunikasi interpersonal guru SMK Negeri 5 Padang menunjukkan skor tertinggi ada pada pernyataan guru tidak menyombongkan diri jika mendapat pujian atau penghargaan dengan tingkat capaian $86,37 \%$ dalam kriiteria baik. Kemudian skor terendah terdapat pada pernyataan guru tidak marah apabila diberikan kritik dan saran oleh siswa dengan perolehan tingkat capaian 73,85\% dalam kriteria cukup baik. Secara keseluruhan penelitian persepsi siswa tentang sikap positif dalam komunikasi interpersonal guru SMK Negeri 5 Padang dengan perolehan tingkat capaian 79,67\% dalam kategori cukup baik 
Hasil penelitian persepsi siswa tentang kesamaan dalam komunikasi interpersonal guru SMK Negeri 5 Padang menunjukkan skor tertinggi berada pada pernyataan guru segera memberikan tanggapannya kepada setiap siswa yang mengajukan pertanyaan kepadanya dengan perolehan tingkat pencapaian $80,88 \%$ dalam kriteria baik. kemudia skor terendah terdapat pada pernyataan guru menerima dengan baik setiap informasi yang disampaikan oleh siswa kepadanya dengan perolehan tingkat capaian 74,07\% dalam kriteria cukup baik. Secara keseluruhan persepsi siswa tentang kesamaan dalam komunikasi interpersonal guru SMK Negeri 5 Padang dengan perolehan tingkat capaian 76,67 dalam kriteria cukup baik.

Hasil akhir penelitian di SMK Negeri 5 Padang mengenai persepsi siwa tentang komunikasi interpersonal guru: Keterbukaan komunikasi interpersonal guru di SMKN 5 Padang menurut persepsi siswa dengan capaian $79,37 \%$ yang berada pada kriteria cukup baik. Empati dalam komunikasi interpersonal guru di SMKN 5 Padang menurut persepsi siswa dengan perolehan tingkat capaian 86,80\% berada pada kriteria baik. Sikap saling mendukung dalam komunikasi interpersonal guru di SMKN 5 Padang menurut persepsi siswa dengan perolehan timgkat capaian $83,41 \%$ dalam kriteria baik. Sikap positif dalam komunikasi interpersonal guru di SMKN 5 Padang menurut persepsi dengan perolehan tingkat capaian 79,67\% dalam kategori cukup baik. Kesamaan dalam komunikasi interpersonal guru di SMKN 5 Padang menurut persepsi siswa dengan perolehan tingkat capaian 76,67 dalam kriteria cukup baik. Secara keseluruhan persepsi siswa tentang komunikasi interpersonal guru SMK Negeri 5 Padang dengan skor 81,18\% pada kriteria baik.

\subsection{Pembahasan}

Berdasarkan hasil penelitian mengenai persepsi siswa tentang keterbukaan komunikasi interpersonal guru SMK Negeri 5 Padang dengan capaian 79,37\% yang berada pada kriteria cukup baik. Hal ini berarti keterbukaan yang ada dalam komunikasi interpersonal belum sesuai dengan apa yang diharapkan, sehingga harus ditingkatkan menjadi sangat baik dan sangat baik. Hasil penelitian skor tertinggi ada pada pernyataan item guru mengemukakan pendapat kepada siswa secara terbuka dengan perolehan tingkat capaian 87,25\% dalam kriteria baik, artinya guru suidah mampu terbuka dalam mengemukakan pendapat kepada issiwa dalam berkomunikasi.

Sedangkan skor terendah pada pernyatan guru bersedia menerima setiap kritikan yang diberikan siswa tentang proses pembelajaran di kelas dengan perolehan tingkat capaian 72,31\% dalam kategori cukup baik, artinya guru belum mampu secara terbuka menerima kritikan dari siswanya sehingga keterbukaan komunikasi interpersonal guru belum mencapai kriteria sangat baik. Menurut (Suranto 2012), keterbukaan merupakan sikap bisa menerima masukan dari orang lain, serta berkenan menyampaikan informasi penting kepada orang lain tersebut, sehingga ada ketersediaan membuka diri untuk mengungkapkan informasi. Keterbukaan sangatlah penting bagi guru untuk meningkatkan komunikasi interpersonalnya. Sifat keterbukaan minimal dititik beratkan pada dua aspek ini, yaitu kita harus terbuka kepada orang yang berinteraksi dengan kita dan kita harus memberikan tanggapan terhadap orang lain secara jujur dan terus terang terhadap sesuatu yang sedang dibahas. Jadi untuk meningkatkan aspek keterbukaan dalam komunikasi interpersonal guru, hendaknya memperhatikan kedua aspek ini.

Berdasarkan hasil penelitian mengenai persepsi siswa tentang empati dalam komunikasi interpersonal guru SMK Negeri 5 Padang dengan perolehan tingkat capaian 86,80\% berada pada kriteria baik. hal ini berarti empati dalam komunikasi interpersonal guru menurut siswa sudah baik, namun perlu ditingkatkan menjadi sangat baik. Hasil penelitian menunjukkan skor tetinggi berada pada pernyataan guru ikut merasa bangga jika ada siswa yang mendapatkan prestasi yang bagus, baik di dalam maupun di luar sekolah dengan perolehan 90,99\% dalam kriteria sangat baik. Artinya sikap empati guru dalam hal ikut merasakan rasa bangga yang dirasakan siisiwa sudah baik, namun perlu ditingkatkanke arah yang lebih baik lagi.

Kemudian skor rendah adalah guru dapat memahami perasaan siswa ketika mengalami kesulitan dalam mengerjakan tugas sekolah, yaitu $83,52 \%$ dalam kriteria baik, hal ini disebabkan karena kurangnya kemampuan guru dalam mengerti dan memahami perasaan atau kondisi siswa. Menurut (Suranto 2012), empati merupakan kemampuan seseorang untuk merasakan jika menjadi orang lain dapat memahami sesuatu yang sedang dialami orang lain, merasakan apa yang dirasakan orang lain, dan memahami sesuatu persoalan dari sudut pandang orang lain. Atau dengan kata lain, menempatkan diri sendiri pada posisi orang lain. Seseorang yang mempunyai sikap empati mampu memahami orang lain di sekitarnya. Untuk meningkatkan aspek empati ini, setidaknya dapat dimulai dari hal menghargai pendengar, mengidentifikasi masalah, saling berbagi masalah, menerima masalahnya (Muhammad 2009).

Berdasarkan hasil penelitian persepsi siswa tentang sikap saling mendukung dalam komunikasi interpersonal guru SMK Negeri 5 Padang dengan perolehan tingkat capaian $83,41 \%$ dalam kriteria baik, hal ini menunjukkan bhwasanya sikap saling mendukung yang ditunjukkan guru dalam komunikasi interpersonal sudah sesuai dengan apa yang diharapkan, selanjutnya perlu ditingkat menjadi lebih baik lagi. Hasil penelitian menunjukkan skor tertinggi ada pada pernyataan guru mengutarakan rasa bangga kepada siswa yang berhasil meraih prestasi dengan perolehan tingkat pencapaian $89,23 \%$ dalam kriteria baik, artinya guru 
mampu menampakkan sikap mendukungnya atas prestasi siswa melalui rasa bangga yang diutarakan baik secara langsung maupun tidak langsung saat siswa mendapat sebuah prestasi.

Selanjutnya, skor terendah terdapat pada pernyataan guru bersedia mendengarkan dengan baiik setiap keluh kesah yang disampaikan siswa dengan perolehan tingkat capaian $72,75 \%$ dalam kriteria cukup baik. Secara keseluruhan persepsi siswa tentang sikap saling mendukung dalam komunikasi interpersonal guru SMK Negeri 5 Padang, disebabkan karena guru kurang memiliki sikap mendukung siswa dalam kondisi apapun. Menurut (Suranto 2012), dukungan merupakan hubungan interpersonal yang efektif antara guru dan siswa, memiliki komitmen untuk mendukung terselenggaranya interaksi secara terbuka. Sikap saling mendukung mampu mengurangi sikap defensif dalam berkomunikasi yang dapat terjadi akibat faktor personal seperti rasa takut ataupun kecemasan sehingga menyebabkan gagalnya komunikasi interpersonal, karena orang defensif akan lebih melindungi diri daripada memahami pesan. Maka di sinilah terlihat pentingnya sikap saling mendukung, baik itu deskriptif maupun spontanitas. Sikap saling mendukung ditunjukkan untuk tercapainya komunikasi interpersonal yang efektif dan meminimalisir gangguan.

Berdasarkan hasil penelitian persepsi siswa tentang sikap positif dalam komunikasi interpersonal guru SMK Negeri 5 Padang dengan perolehan tingkat capaian 79,67\% dalam kategori cukup baik, hal ini menunjukkan bahwasanya sikap positif guru beum sesuai dengan yang diharapkan, sehingga harus ditingkatkan menjadi lebih baik. Hasil penelitian menunjukkan skor tertinggi ada pada pernyataan guru tidak menyombongkan diri jika mendapat pujian atau penghargaan dengan tingkat capaian 86,37\% dalam kriiteria baik, artinya guru bersifat rendah hati saat dipuji dan diberi penghargaan.

Kemudian skor terendah terdapat pada pernyataan guru tidak marah apabila diberikan kritik dan saran oleh siswa dengan perolehan tingkat capaian $73,85 \%$ dalam kriteria cukup baik, disebabkan karena guru kurang mampu untuk menerima kritik dan saran dari siswanya. Sikap positif harus dimiliki setiap individu terhadap dirinya sendiri, mendorong orang lain lebiih aktif berpartisipasi, serta menciptakan komunikasi interpersonal yang efektif. Sikap positif yang dimaksud di sini adalah dimana guru secara rendah hati dalam berkomunikasi dengan siswanya baik di dalam maupun di luar kelas, serta guru mau mempertanggungjawabkan segala bentuk informasi yang disampaikan kepada siswa. Sikap positifi ini tentunya akan memicu atau mengakibatkan komunikasi interpersonal yang efektif.

Berdasarkan hasil penelitian persepsi siswa tentang kesamaan dalam komunikasi interpersonal guru SMK Negeri 5 Padang dengan perolehan tingkat capaian 76,67 dalam kriteria cukup baik, hal ini menunujukkan bahwasanya kesamaan ini belum terwujud dengan apa yang semestinya sehingga harus ditingkatkan kea rah yang lebih baik sehingga dapat terwujud sesuai yang seharuusnya. Hasil penelitian menunjukkan skor tertinggi berada pada pernyataan guru segera memberikan tanggapannya kepada setiap siswa yang mengajukan pertanyaan kepadanya dengan perolehan tingkat pencapaian $80,88 \%$ dalam kriteria baik, respon yang sama terhadap sisiwa yang mengajukan pertanyaan sudah baik, dan perlu ditingkatkan untuk menjadi sangat baik.

Kemudia skor terendah terdapat pada pernyataan guru menerima dengan baik setiap informasi yang disampaikan oleh siswa kepadanya dengan perolehan tingkat capaian 74,07\% dalam kriteria cukup baik, penyebab karena guru belum bisa mengakui setiap siswa itu sama sehingga kurannya arasa kepercayaan kepada siswa, hal ini sejalan dengan pendapat Gibb (Muhammad, 2009) bahwasanya kesamaan ini adalah saling percaya dan menghargai, terlihat dalam perbuatan perncanaan tanpa mempengaruhi kekuasaan, status atau penampilan. Selanjutnya menurut (Suranto 2012), kesamaan adalah dimana keduabelah pihak ada pengakuan secara diam-diam bahwa kedua pihak sama-sama bernilai dan berharga, dan bahwa masingmasing pihak saling memerlukan. Komunikasi interpersonal yang efektif akan membantu kita mengantarkan kepada tercapainya tujuan tertentu. Seorang guru yang ingin mentransfer pengetahuan dan membimbing sikap siswanya, tidak sekedar ditentukan oleh ilmu pengetahuan yang dia miliki, melainkan ditentukan pula oleh bagaimana cara dia berkomunikasi. Sebaliknya, jika komunikasi interpersonal tidak berhasil, akibatnya apa saja, dari sekedar membuang waktu, sampai akibat buruk lainnya. Jadi, untuk meningkatkan aspek kesamaan ini perlu adanya menumbuh kembangkan sikap saling percaya, menghargai dan saling terlibat antar kedua belah pihak dalam berkomunikasi. Ketiga sikap inilah yang akan menciptkan aspek kesamaan yang sangat baik jika sudah dikembangkan dengan baik.

\section{Kesimpulan}

Berdasarkan hasil penelitian dan pembahasan maka dapat disimpulkan: Keterbukaan komunikasi interpersonal guru di SMKN 5 Padang menurut persepsi siswa dengan capaian 79,37\% yang berada pada kriteria cukup baik. Empati dalam komunikasi interpersonal guru di SMKN 5 Padang menurut persepsi siswa dengan perolehan tingkat capaian $86,80 \%$ berada pada kriteria baik. Sikap saling mendukung dalam komunikasi interpersonal guru di SMKN 5 Padang menurut persepsi siswa dengan perolehan timgkat capaian $83,41 \%$ dalam kriteria baik. Sikap positif dalam komunikasi interpersonal guru di SMKN 5 Padang menurut persepsi dengan perolehan tingkat capaian 79,67\% dalam kategori cukup baik. Kesamaan dalam komunikasi interpersonal guru di SMKN 5 Padang menurut persepsi siswa dengan perolehan tingkat capaian 76,67 dalam 
kriteria cukup baik. Secara umum komunikasi interpersonal guru di SMKN 5 Padang menurut persepsi siswa berada dengan skor $81,18 \%$ pada kriteria baik.

\section{Daftar Rujukan}

Al-Madani, F.M. 2014. "Relationship Between Teachers' Effective Communication and Students' Academic Achievement at The Northern Border University." European Journal of Educational Research 4(2): 90 96.

Azrimul, and Masyhuri. 2013. "Hubungan Antara Komunikasi Interpersonal Dengan Iklim Organisasi Pada Pegawai SMA Negeri 1 XIII Koto KamparKabupaten Kampar-Riau.” Menara Vol. 12, N.

Cangara, H. Hafied. 2004. Pengantar Ilmu Komunikasi. Jakarta: Raja Grafindo Persada.

F., Haq, and Rahmah Mawizha. 2018. "Komunikasi Interpersonal Guru Dalam Memotivasi Belajar Siswa SMK TPI Gedangan Sidoarjo." UIN Sunan Ampel Surabaya.

Fathurrohman, Ivan. 2018. "Pengaruh Komunikasi Interpersonal Guru Dengan Siswa Terhadap Perilaku Belajar Siswa Dalam Mewujudkan Prestasi Belajar Siswa." Khazanah Akademia 02: 13-21.

Fauziah, Insani. 2014. "Kontribusi Komunikasi Interpersonal Terhadap Kepuasan Kerja Pegawai Di Dinas Sosial Dan Tenaga Kerja Kota Padang." UNP.

Gistituati, Nurhizrah. 2009. Manajemen Pendidikan: Budaya Dan Kepemimpinan Organisasi. Padang: UNP Press.

Gustyawan, Reindy. 2015. "Pengaruh Komunikasi Interpersonal Terhadap Kinerja Karyawan Di Divisi Sekretaris Perusahaan PT Dirgantara Indonesia (Persero).” E-Proceeding of Management Vol. 2, No.

Henderson, Rebecca R. 2013. "Organizational Citizenship Behavior, Communication and the Relationship to Student Achievement and School Size." ERIC Numbe.

Liliweri, Alo. 2015. Komunikasi Antarpersonal. Jakarta: Kencana.

Muhammad, Arni. 2009. Komunikasi Organisasi. Jakarta: Bumi Aksara.

Regina, Yolanda. 2016. "Pengaruh Komunikasi Interpersonal Guru Dan Pembelajaran Kontekstual Terhadap Komitmen Belajar Siswa Pada Mata Pelajaran PKN Di SMPN 1 Tanjung Raja Kabupaten Lampung Utara Tahun Pelajaran 2015/2016." Universitas Lampung.

Remanda, Fariz. 2012. "Pengaruh Komunikasi Interpersonal Terhadap Kinerja Pegawai Di Dinas Pekerjaan Umum Kota Pekanbaru." UIN SUSKA Riau.

Rizaldi, Andi Radhitya, and Reni Nuraeni. 2013. "Pengaruh Komunikasi Interpersonal Terhadap Kepuasan Kerja Karyawan." Universitas Telkom.

Rozaq, Fadli. 2012. "Hubungan Komunikasi Interpersonal Antara Guru Dan Siswa Dengan Keaktifan Belajar Siswa Kelas XI Program Keahlian Teknik Otomotif Di SMK Muhammadiyah 4 Klaten Tengah Tahun Ajaran 2012/2013." UNY.

Sugiyono. 2015. Metode Penelitian Kuantitatif, Kualitatif, Dan $R \& D$. Bandung: Alfabeta.

Suranto, AW. 2012. Komunikasi Interpersonal. Yogyakarta: Graha Ilmu.

Usman, Fahrul. 2015. "Pengaruh Komunikasi Interpersonal Guru Terhadap Minat Belajar Pada Mata Pelajaran Matematika Siswa Kelas VII Di SMP Pesantren IMMIM Putra Makassar.” Nalar Pendidikan 3: 63-67.

Üstüner, M., and A. Kiş. 2014. "The Relationship between Communication Competence and Organizational Conflict: A Study on Heads of Educational Supervisors." Eurasion Journal of Educational Research 56: $23-44$.

Wadudu, Halim. 2013. “Analisis Pengaruh Komunikasi Interpersonal Terhadap Kinerja Pegawai.” Universitas Tribhuwana Tunggadewi.

Wijaya, Ida Suryani. 2013. "Komunikasi Interpersonal Dan Iklim Komunikasi Dalam Organisasi.” . Jurnal Dakwah Tabligh Vol. 14, N.

Yusuf, A Muri. 2017. Metode Penelitian: Kuantitatif, Kualitatif Dan Penelitian Gabungan. Jakarta: Kencana.

Yusuf, Andi Muhammad. 2017. "Pengaruh Komunikasi Interpersonal Guru Terhadap Prestasi Belajar Siswa SMKN 7 Makassar." UIN Alauddin Makassar. 
